\title{
Characterization and Classification of Soils along the Toposequence of Kindo Koye Watershed in Southern Ethiopia
}

\author{
Mulugeta Demiss $^{1 *}$ and Sheleme Beyene ${ }^{2}$ \\ ${ }^{1}$ MoA, P O Box 62347, Addis Ababa, Ethiopia \\ ${ }^{2}$ Hawassa University, P O Box 05 Hawassa, Ethiopia
}

\begin{abstract}
In developing countries, where research funds are limited, the availability of pedogenic information and proper classification of soils will be of great importance. The soils of Kindo Koye watershed were fully characterized along east and west facing toposequences that formed a catena and classified according to the Soil Taxonomy and the WRB Legend to assess the impact of topography on soil development and characteristics. The morphological and physiochemical properties of seven pedons located at the upper, middle and lower slopes of the two toposequences and at the depression were studied. The study revealed the existence of three different soil orders along the toposequences in an area that was previously mapped as Eutric Nitosols. The pedons on the upper and middle slopes of both east and west-facing toposequences and the pedon on the east-facing lower slope were categorized under Ultisols, whereas the pedons on the foot slope west-facing and the depression were categorized under Inceptisols and Entisols, respectively. The Ultisols, Inceptisols and Entisols were further categorized as Acrisols, Cambisols and Fluvisols major groups according to the WRB Legend, respectively. This detail survey and classification of soils shows that topography has a great influence on soil development and characteristics.
\end{abstract}

Keywords: Catena; Toposequence; Pedon; Soil Taxonomy; WRB Legend

\section{Introduction}

In developing countries, where research funds are limited, the availability of pedogenic information and proper classification of soils will be of great importance in adopting well tested management technologies and landscape positions without going through the whole process of time consuming and expensive technology selection trials as this will provide the basic information for sustainable agricultural planning (Fikre, 2003). There has not been a comprehensive compilation on soils of Ethiopia, though the felt need for a process-oriented instruction text and as a suitable reference has long been recognized. Even the limited findings are not easily accessible to those who might wish to utilize them (Mesfin, 1998). Consequently, sustainable soil management practices that are based on the understanding of soil systems are not available for most parts of the country (Fikre, 2003).

Landscapes position influences runoff, drainage, soil temperature, soil erosion, soil depth and hence soil formation. Different soil properties encountered along landscapes will affect the patterns of plant production, litter production and decomposition, which will definitely have effects on carbon (C) and nitrogen $(\mathrm{N})$ contents of the soil. Soil properties such as clay content and its distribution with depth, sand content and $\mathrm{pH}$ have been shown to be highly correlated with landscape position (Wang et al., 2000) while organic matter has been shown to vary with slope position (Miller et al., 1998).

Soils on steep upper slopes range from moderately deep to shallow. They are well drained with the gravelly and channery silt loam and sandy loam textures commonly associated with rock outcrops. These soils generally have severe erosion potential from exposed or bare soil areas and a greater risk of slope failure. Soils in mid-slope and toe or lower slope positions are usually deep, well-drained, gravelly silt loams, whereas those below prominent sandstone cliffs

*Corresponding author. E-mail: Mulugetadem@gmail.com are usually sandy loams (www.fs.fed.us/r8/boone Lresources/soil/index.shtml 03/08/2009). In the lowest landscape positions, water may saturate the regolith to such a degree that drainage and aeration are restricted. Here, the weathering of some minerals and the decomposition of organic matter are retarded, while the loss of iron and manganese is accelerated. In such low-lying topography, special profile features characteristic of wetland soils may develop (Brady and Weil, 2002).

The Ethiopian Mapping Authority (EMA, 1988) characterized the soils of Wolayita areas as Eutric Nitosols. But the Authority used a very small-scale survey that does not specifically tell about the areas considered in this study. Thus, the present study was initiated to fully characterize and classify the soils of the catena following the Soil Taxonomy (Soil Survey Staff, 1999) and the WRB Legend (FAO/WRB, 2006) systems to assess the impact of topography on soil development and characteristics.

\section{Materials and Methods}

\subsection{Description of the Site}

The study was conducted at the Kindo Koye watershed, Damot Woyde Woreda, Wolayita Zone, Southern Nations, Nationalities and Peoples' Regional State (SNNPRS). The watershed is located at the coordinates between $6^{\circ} 52.82^{\prime}$ and $6^{\circ} 53.41^{\prime} \mathrm{N}$ and $37^{\circ} 52.42^{\prime}$ and $37^{\circ} 52.63^{\prime} \mathrm{E}$ with altitude ranging from 1970 to 2061 meters above sea level (masl). The region has a humid climate with an average annual temperature of $20{ }^{\circ} \mathrm{C}$. The monthly mean temperatures range from $17.2{ }^{\circ} \mathrm{C}$ in July to $21.9^{\circ} \mathrm{C}$ in February. The average annual precipitation is about $1333 \mathrm{~mm}$ with monthly minimum and maximum recorded values of 29 $\mathrm{mm}$ and $218 \mathrm{~mm}$ in the months of January and July, respectively (FAO, 1984). Eighty three percent of the rainfall falls between April and October every year. The major crops and grasses along the selected toposequence 
include maize (Zea mays), barley (Hordem vulgare), sweet potato (Ipomoea batatas), sugarcane (Saccarum officinarum), and teff (Eragrotis teff) and grasses such as Digitaria diagonalis. Besides these, plantations dominated by eucalyptus trees (Eucalyptus camaldulensis) were present. The soils of the study area are developed on basaltic parent material. According to the WRB Soil Classification System, Eutric Nitosols are the dominant soil units (EMA, 1988).

\subsection{Soil Profile Site Selection, Description and Sampling}

A catena was selected along east-west facing slopes (toposequences) encompassing landform components spanning from ridge top to valley bottom. The slopes along the toposequences ranged from 0.5 to $25 \%$. The toposequences were divided into three slope categories namely upper slope, middle slope and foot slope, and depression at the center. A total of six pedons with $2 \mathrm{~m}$ length, $2 \mathrm{~m}$ width and $2 \mathrm{~m}$ depth were excavated one each on upper slope west-facing (UWF), middle slope westfacing (MWF), foot slope west-facing (FWF), foot slope east-facing (FEF), middle slope east-facing (MEF) and upper slope east-facing (UEF) and the seventh with $3 \mathrm{~m} \times 3$ $\mathrm{m}$ and $3 \mathrm{~m}$ dimension at the depression (DEP) (Table 1). The soil profiles of all the sampling slopes and aspects were described in situ following the guidelines for soil profile description (FAO, 1990) and samples were collected from all identified horizons. Freshly excavated sites were used for sampling and profile description. Core sampler was used to collect undisturbed soil samples from each horizon to determine bulk density. The total area of the study site was 65 ha. The east-facing toposequence is 31 ha and the westfacing one is 34 ha.

Table 1. Description of soil profile site characteristics.

\begin{tabular}{ccclll}
\hline Pedon & Slope $(\%)$ & Altitude (masl) & Surrounding landform & Physiographic position & Parent material \\
\hline UEF & 13 & 2010 & Gentle slope & Upper slope & Basaltic \\
MEF & 20 & 1997 & Steep slope & Middle slope & Basaltic \\
FEF & 25 & 1984 & Steep slope & Foot slope & Colluvium/Basaltic \\
FWF & 12 & 1976 & Steep slope & Foot slope & Colluvium/Basaltic \\
MWF & 18 & 2002 & Steep slope & Middle slope & Basaltic \\
UWF & 10 & 2029 & Gentle slope & Upper slope & Basaltic \\
DEP & 0.5 & 1970 & Gentle/flat & Depression & Alluvium/colluvium \\
\hline UWF = Upper slope west-facing; $M W F=$ Middle slope west-facing; FWF = Foot slope west-facing; DEP = Depression; UEF = Upper slope \\
east-facing; MEF = Middle slope east-facing; FEF = Foot slope east-facing
\end{tabular}

\subsection{Soil Analysis}

The soil samples collected from every identified horizon were air-dried and ground to pass through $2 \mathrm{~mm}$ sieve. For the determinations of total $\mathrm{N}$ and organic carbon (OC), a $0.5 \mathrm{~mm}$ sieve was used. Analysis of the physico-chemical properties of the soil samples were carried out following standard laboratory procedures.

Bulk density was determined using the core-sampling method (BSI, 1975). Particle size distribution was analyzed by the hydrometer method (Sahlemedhin and Taye, 2000) using hydrogen peroxide $\left(\mathrm{H}_{2} \mathrm{O}_{2}\right)$ to oxidize organic matter and sodium hexameta phosphate $\left(\mathrm{NaPO}_{3}\right)$ as a dispersing agent. Soil $\mathrm{pH}$ was determined in $\mathrm{H}_{2} \mathrm{O}$ and $0.1 \mathrm{M} \mathrm{KCl}$ using 1:2.5 soils to solution ratio using a combined glass electrode $\mathrm{pH}$ meter (Chopra and Kanwar, 1976) and change in $\mathrm{pH}$ was determined by subtracting soil $\mathrm{pH}(\mathrm{KCl})$ from soil $\mathrm{pH}$ $\left(\mathrm{H}_{2} \mathrm{O}\right)$. Cation exchange capacity and exchangeable bases were determined using the $1 \mathrm{M}$-ammonium acetate $(\mathrm{pH} 7)$ method followed by repeated washing with ethanol $(96 \%)$ to remove the excess ammonium ions in the soil solution according to the percolation tube procedure (Van Reeuwijk, 1993) and the base saturation (BS) and exchangeable sodium percentages (ESP) were computed.

Total $\mathrm{N}$ was analyzed by the Kjeldahal digestion and distillation procedure (Bremner and Mulvaney, 1982), whereas OC was determined following the wet combustion method of Walkley and Black as outlined by Van Ranst et al. (1999). Available phosphorus (P) content of the soils was analyzed using the Olsen method as outlined by Van
Reeuwijk (1993). Available micronutrients (Fe, Mn, Zn, and $\mathrm{Cu}$ ) contents of the soils were extracted by the diethylene triamine pentaacetic acid (DTPA) extraction method (Tan, 1996) all were quantified using atomic absorption spectropotometer .

Finally, analysis of simple correlation coefficient among the different soil physical and chemical properties was carried out using SAS (1997) software to reveal the magnitude and direction of relationships between each other.

\section{Results and Discussion 3.1. Soil Morphological Features}

Distinct horizons/layers and argillic B-horizons were observed in the pedons, except for the FWF and depression area. Three of the pedons, MEF, FEF and UWF, had Ap and $\mathrm{Bt}$; the UEF had Ap, BA and Bt; the MWF had Ap, AB and $\mathrm{Bt}$; and the FWF had Ap, AB and B, whereas the pedon at the depression had $\mathrm{A}, \mathrm{AC}$ and $\mathrm{C}$ horizon sequences (Table 2).

The depths of the A-horizons decreased with increasing slope (Table 2). Accordingly, the DEP (0.5\% slope) and MEF (20\% slope) had the deepest and shallowest Ahorizons, respectively. The soils at the shoulders tend to be shallower due to erosion, whereas the soils on the foot slope and toe-slope areas tend to be thicker as a result of deposition. Erosion causes stripping of the soil thus preventing the material to stay in place to develop into a soil. The greatest erodibility was associated with the upper 
slope positions where soils tended to be shallow, coarse in texture and low in organic matter (OM), while lower erodibility was observed at the lower slope positions with deep, organic-rich and leached soils (Lawrence, 1992). Irvin (1996) who related landform elements to soil properties stated that generally, an increase in slope is associated with a reduction in: leaching, OM content, clay translocation, mineral weathering, horizon differentiation, and solum thickness.

Surface soil color (moist) ranged from very dusky red (2.5YR 2/2) to very dark brown (7.5YR 2.5/2) except in the pedon of the depression, whereas the color (moist) of the subsurface horizons varied from dark reddish brown $(2.5 \mathrm{YR}$ $2.5 / 3$ ) to very dark brown (7.5YR 2.5/3) (Table 2). The moist soil colors of the horizons in the pedon at the depression, however, varied from reddish brown (5YR 4/4) to very dark brown (7.5YR 2.5/3).

The results showed that soil color is highly influenced by soil OM, where the darkness in the A-horizon decreased with depth. Dark colored surface horizons (values $\leq 3$ ) are often enriched with OM, offering many benefits to the soil (soils.missouri.edu/tutorial/page7.asp 03/08/2009). Soils on slopes that were never saturated with water had reddish and brownish subsoil colors, which are indicatives of welldrained and aerated conditions. Reddish color is due to the presence of iron compounds in various states of oxidation and hydration (Foth, 1990). The horizons in the pedon at the depression varied in color from the others due to reduction reactions caused by water saturation. Pedons that collect water, and are on poorly drained locations where soils are water saturated much of the time, will tend to have grey-colored B-horizons (Foth, 1990). Topography affects the amount of surface runoff, erosion and deposition. If erosion removes soil from the shoulder or back-slope areas of a hill-slope, thinner and light-colored soils remain where the OM content is low. Soils found on foot-slope or toeslope areas generally show a higher OM content and thicker A- horizon (grunwald.ifas.ufl.edu/Nat_resources/organic_ matter/organic.htm 02/08/2009).

The moist consistence of the soils ranged from friable to extremely firm, whereas the wet consistence ranged from slightly sticky/slightly plastic to very sticky/very plastic (Table 2). Despite high clay contents of up to $81 \%$ (Table 3 ), the soil materials were not extremely sticky (Table 2) probably because of the type of clay mineral present. Many red colored tropical soils have clay particles composed mainly of kaolinite and oxides of iron and aluminum, which have little capacity to develop stickiness and to expand and contract on wetting and drying (Foth, 1990). The very friable and friable consistence observed in the surface soils of the pedons (Table 2) could be attributed to the higher OM contents of the layers (Table 5). Although consistence is an inherent soil characteristic, the presence of high OM in the surface horizon changes its consistence (Wakene and Heluf, 2004).

\subsection{Soil Physical Properties}

\subsubsection{Particle Size Distribution}

The soil texture varied from clay loam to clay in the surface horizons of all pedons (Table 3) and became finer from the upper to the middle of the toposequences which may be due to removal of fine soil particles from steeper slope positions by erosion. According to Lawrence (1992), of the individual soil properties considered, silt and sand contents were the most highly correlated with erodibility. Moore et al. (1993) found that slope was one of the topographic factors which was most highly correlated with soil properties. The investigators have reported that slope was positively correlated with sand content and negatively correlated with silt content, and high OM mainly occurred when slopes were less than $2 \%$. The sediment transport was different for each soil particle size. The transport of coarse-sized particles (sand) was lowest, whereas the transport of fine soil particles (clay) and medium-sized particles (silt) was high. If erosion occurs on a hill-slope, the silt content often is higher in the bottom soils compared to the soils on the hillslope shoulder (grunwald.ifas.ufl.edu/Nat_resources/soil_ forming_factors/formation.htm 02/08/2009).

The subsurface horizons of most pedons were finer in texture than their respective surface horizons, indicating that there was a prominent translocation of clay down the profiles forming argillic horizons. However, the texture of the subsoil horizons of the pedon at the west-facing foot slope was more or less similar to that of its surface horizon, whereas the pedon at the depression possessed coarser (sandy clay loam) texture as compared to the clay texture of its surface horizons (Table 3), which could be attributed to successive deposition of contrasting materials.

Change in clay percentages down the soil profile suggests pedogenic eluviation-illuviation processes, particularly in the upper as well as middle slope profiles. The presence of faint to prominent clay coatings in the subsurface horizons of the five pedons also indicates that clay illuviation/translocation was the main factor for the formation of argillic horizon in the pedons. The in situ synthesis of secondary clays, the weathering of primary minerals in the B-horizon, or the residual concentration of clays from the selective dissolution of more soluble minerals in the B-horizon could have also contributed to the accumulation of clays in the subsoil horizons (Rust, 1983; Chadwick and Grahm, 2000; Buol et al., 2003). 
Table 2. Morphological features and physical properties of the soils along the toposequences at Kindo Koye watershed.

\begin{tabular}{|c|c|c|c|c|c|c|c|}
\hline \multirow[b]{2}{*}{ Horizon } & \multirow{2}{*}{$\begin{array}{c}\text { Depth } \\
\text { (cm) }\end{array}$} & \multirow[b]{2}{*}{ Color (moist) } & \multirow[b]{2}{*}{ Field texture } & \multirow[b]{2}{*}{ Structure* } & \multicolumn{2}{|c|}{ Consistence } & \multirow{2}{*}{$\begin{array}{l}\text { Horizon } \\
\text { boundary }\end{array}$} \\
\hline & & & & & Moist & Wet & \\
\hline \multicolumn{8}{|c|}{ Upper slope east-facing (UEF) Pedon } \\
\hline Ap1 & $0-40$ & 7.5YR 2.5/2 & Loam & VW, FI, GR & VFI & SST-SPL & G-S \\
\hline Ap2 & $40-64$ & 7.5YR 2.5/2 & Clay loam & $\mathrm{MO}, \mathrm{ME}, \mathrm{SB}$ & VFI & ST-PL & C-S \\
\hline $\mathrm{BA}$ & $64-90$ & $5 Y R 3 / 3$ & Clay & $\mathrm{ST}, \mathrm{ME}, \mathrm{AB}$ & FI & VST-VPL & C-S \\
\hline Bt1 & $90-136$ & 7.5YR $2.5 / 2$ & Clay & $\mathrm{ST}, \mathrm{ME}, \mathrm{AB}$ & FI & VS-VP & G-S \\
\hline $\mathrm{Bt} 2$ & $136^{+}$ & $2.5 \mathrm{YR} 2.5 / 4$ & Clay & $\mathrm{ST}, \mathrm{ME}, \mathrm{AB}$ & VFI & VS-VP & - \\
\hline \multicolumn{8}{|c|}{ Middle slope east-facing (MEF) Pedon } \\
\hline $\mathrm{Ap}_{1}$ & $0-14$ & $2.5 \mathrm{YR} 2 / 2$ & Clay & VW, ME, GR & FR & ST-PL & C-S \\
\hline $\mathrm{Ap}_{2}$ & $14-40$ & $2.5 Y R 3 / 3$ & Clay & $\mathrm{VW}, \mathrm{FM}, \mathrm{AB}$ & FR & ST-PL & G-S \\
\hline Bt1 & $40-53$ & 2.5YR $2.5 / 4$ & Clay & $\mathrm{MO}, \mathrm{FM}, \mathrm{AB}$ & EFI & VST-VPL & G-S \\
\hline Bt2 & $53-117$ & $2.5 Y R 3 / 3$ & Clay & VS, FM, SB & EFI & VST-VPL & G-S \\
\hline Bt3 & $117-165$ & $2.5 \mathrm{YR} 3 / 6$ & Clay & $\mathrm{ST}, \mathrm{ME}, \mathrm{AB}$ & EFI & VST-VPL & G-S \\
\hline Bt4 & $165^{+}$ & $2.5 \mathrm{YR} 3 / 4$ & Clay & ST, ME, AB & EFI & VST-VPL & - \\
\hline \multicolumn{8}{|c|}{ Foot slope east-facing (FEF) Pedon } \\
\hline $\mathrm{Ap}_{1}$ & $0-18$ & $7.5 Y R 2 / 3$ & Clay loam & VW, ME, GR & FR & SST-SPL & G-S \\
\hline $\mathrm{Ap}_{2}$ & $18-53$ & $5 \mathrm{YR} 3 / 2$ & Clay loam & WE, ME, GR & FR & SST-SPL & G-S \\
\hline Bt1 & $53-100$ & $2.5 Y R 2.5 / 3$ & Silty clay & WE, ME, AB & FR & SST-SPL & G-S \\
\hline Bt2 & $100-160$ & 2.5YR $2.5 / 3$ & Silty clay & $\mathrm{MO}, \mathrm{ME}, \mathrm{AB}$ & FI & SST-SPL & D-S \\
\hline Bt3 & $160^{+}$ & 5YR 3/4 & Clay & ST, ME, AB & VFI & ST-PL & - \\
\hline \multicolumn{8}{|c|}{ Foot slope west-facing (FWF) Pedon } \\
\hline Ap1 & $0-17$ & 7.5YR 2.5/3 & Clay & WE, FI, GR & FR & SST-SPL & G-S \\
\hline Ap2 & $17-37$ & $7.5 Y R 3 / 3$ & Clay & WE, ME, SB & FR & SST-SPL & G-S \\
\hline $\mathrm{AB}$ & $37-54$ & 7.5YR $2.5 / 3$ & Clay & $\mathrm{MO}, \mathrm{FI}-\mathrm{ME}, \mathrm{AB}$ & FR & SST-SPL & G-S \\
\hline B1 & $54-71$ & 7.5YR $2.5 / 3$ & Clay & ST, FI-ME, AB & FR & SST-SPL & G-S \\
\hline B2 & $71-112$ & $7.5 \mathrm{YR} 3 / 3$ & Clay & ST, FI-ME, AB & FR & SST-SPL & G-S \\
\hline B3 & $112-133$ & 7.5YR $3 / 3$ & Clay & ST, FI-ME, AB & FR & SST-SPL & G-S \\
\hline B4 & $133^{+}$ & 7.5YR $3 / 3$ & Clay & ST, FI-ME, AB & FR & SST-SPL & - \\
\hline \multicolumn{8}{|c|}{ Middle slope west-facing (MWF) Pedon } \\
\hline $\mathrm{Ap}_{1}$ & $0-22$ & $2.5 Y R 3 / 4$ & Loam & WE, VF, GR & FR & SST-SPL & C-S \\
\hline $\mathrm{Ap}_{2}$ & $22-43$ & $2.5 \mathrm{YR} 3 / 3$ & Clay & WE, FI, AB & FR & SST-SPL & A-S \\
\hline $\mathrm{AB}$ & $43-75$ & $5 Y R 3 / 3$ & Clay & $\mathrm{MO}, \mathrm{FM}, \mathrm{AB}$ & FR & ST-PL & D-S \\
\hline Bt1 & $75-95$ & $5 Y R 3 / 3$ & Clay & $\mathrm{ST}, \mathrm{ME}, \mathrm{AB}$ & FR & ST-PL & D-S \\
\hline $\mathrm{Bt} 2$ & $95-142$ & $2.5 \mathrm{YR} 3 / 6$ & Clay & ST, ME, SB & FR & ST-PL & D-S \\
\hline Bt3 & $142^{+}$ & 2.5YR 3/4 & Clay & $\mathrm{ST}, \mathrm{ME}, \mathrm{AB}$ & FR & ST-PL & - \\
\hline \multicolumn{8}{|c|}{ Upper slope west-facing (UWF) Pedon } \\
\hline A1 & $0-38$ & 7.5YR 2.5/2 & Clay loam & WE, FM,GR & VFR & ST-SS & G-D \\
\hline A2 & $38-78$ & 7.5YR 2.5/3 & Clay loam & VW, FM, GR & VFR & ST-PL & G-S \\
\hline Bt1 & $78-102$ & $5 Y R 3 / 2$ & Clay & WE, FM, SB & VFI & VST-VPL & A-S \\
\hline Bt2 & $102-171$ & $5 Y R 3 / 3$ & Clay & FI, FM, AB & VFI & VST-VPL & G-S \\
\hline Bt3 & $171^{+}$ & 2.5YR 2.5/4 & Clay & FI, ME, AB & VFI & VST-VPL & - \\
\hline \multicolumn{8}{|c|}{ Depression (DEP) Pedon } \\
\hline A1 & $0-20$ & $5 Y R 3 / 3$ & Clay loam & WE, FM, G & FR & ST-SPL & G-S \\
\hline A2 & $20-50$ & 7.5YR 3/3 & Clay loam & WE, FM, SB & FR & ST-SPL & G-S \\
\hline A3 & $50-70$ & $7.5 Y R 2.5 / 3$ & Sandy loam & WE, M, SB & FR & ST-SPL & G-S \\
\hline $\mathrm{AC} 1$ & $70-95$ & 7.5YR 3/4 & Sandy loam & VW, C, SB & $\mathrm{LO}$ & ST-SPL & G-S \\
\hline AC2 & $95-120$ & $5 Y R 3 / 2$ & Silty clay & MS & FR & ST-SPL & G-S \\
\hline C1 & $120-150$ & $5 Y R 3 / 3$ & SCL & SG & $\mathrm{LO}$ & ST-SPL & G-S \\
\hline $\mathrm{C} 2$ & $150-170$ & $5 Y R 3 / 2$ & SCL & SG & $\mathrm{LO}$ & ST-SPL & A-S \\
\hline C3 & $170-200$ & $5 Y R 3 / 3$ & Clay loam & MS & FI & ST-PL & A-S \\
\hline $\mathrm{C} 4$ & $200-209$ & $5 Y R 3 / 3$ & SCL & MS & $\mathrm{LO}$ & ST-PL & A-S \\
\hline C5 & $209-230$ & $5 Y R 3 / 3$ & Clay loam & MS & FI & ST-SPL & G-S \\
\hline C6 & $230-255$ & $5 \mathrm{YR} 3 / 3$ & Sandy loam & MS & $\mathrm{LO}$ & ST-PL & A-S \\
\hline $\mathrm{C} 7$ & $255^{+}$ & $5 Y R 3 / 3$ & Clay & MS & $\mathrm{FI}$ & VST-VPL & - \\
\hline
\end{tabular}

*WE = Week; $V W=$ Very weak; FM = Fine and medium; GR = Granular; $A B=$ Angular blocky; $S B=S$ Sub angular blocky; FR $=$ Friable; VFR = Very friable; FI = Firm; VFI = Very firm; EFI = Extremely firm; SST-SPL = Slightly sticky and slightly plastic; ST-PL = Sticky and plastic; VST-VPL = Very sticky and very plastic; G-S = Gradual and smooth; $C--S=C l e a r$ and smooth; D-S = Diffuse and smooth; $A-S=$ Abrupt and smooth; $M O=$ Moderate; SCL = Sandy clay loam; $M E=$ Medium; LO = Loose 
Table 3. Particle size distribution and bulk density of the soils in Kindo Koye watershed catena.

\begin{tabular}{|c|c|c|c|c|c|c|}
\hline Horizon & Depth $(\mathrm{cm})$ & Sand $(\%)$ & Silt $(\%)$ & Clay $(\%)$ & Textural class & Bulk density $\left(\mathrm{g} \mathrm{cm}^{3}\right)$ \\
\hline \multicolumn{7}{|c|}{ Upper slope East-facing (UEF) Pedon } \\
\hline Ap1 & $0-40$ & 31 & 38 & 31 & Clay loam & 1.33 \\
\hline Ap2 & $40-64$ & 23 & 30 & 47 & Clay & 1.26 \\
\hline BA & 64-90 & 21 & 28 & 51 & Clay & 1.46 \\
\hline Bt1 & $90-136$ & 11 & 12 & 77 & Clay & 1.42 \\
\hline Bt2 & $136^{+}$ & 9 & 10 & 81 & Clay & 1.33 \\
\hline \multicolumn{7}{|c|}{ Middle slope East-facing (MEF) Pedon } \\
\hline$A p_{1}$ & $0-14$ & 30 & 32 & 38 & Clay loam & 1.36 \\
\hline $\mathrm{Ap}_{2}$ & $14-40$ & 24 & 28 & 48 & Clay & 1.31 \\
\hline Bt1 & $40-53$ & 20 & 20 & 60 & Clay & 1.33 \\
\hline Bt2 & $53-117$ & 18 & 16 & 66 & Clay & 1.34 \\
\hline Bt3 & $117-165$ & 16 & 12 & 72 & Clay & 1.66 \\
\hline Bt4 & $165^{+}$ & 20 & 12 & 68 & Clay & 1.35 \\
\hline \multicolumn{7}{|c|}{ Foot slope East-facing (FEF) Pedon } \\
\hline$A p_{1}$ & $0-18$ & 32 & 30 & 38 & Clay loam & 1.34 \\
\hline $\mathrm{Ap}_{2}$ & $18-53$ & 26 & 34 & 40 & Clay & 1.21 \\
\hline Bt1 & $53-100$ & 22 & 20 & 58 & Clay & 1.49 \\
\hline $\mathrm{Bt} 2$ & $100-160$ & 18 & 20 & 62 & Clay & 1.42 \\
\hline $\mathrm{Bt} 3$ & $160^{+}$ & 24 & 16 & 60 & Clay & 1.42 \\
\hline \multicolumn{7}{|c|}{ Foot slope West-facing (FWF) Pedon } \\
\hline Ap1 & $0-17$ & 30 & 28 & 42 & Clay & 1.35 \\
\hline Ap2 & $17-37$ & 34 & 26 & 40 & Clay & 1.49 \\
\hline $\mathrm{AB}$ & $37-54$ & 34 & 24 & 42 & Clay & 1.35 \\
\hline B1 & $54-71$ & 32 & 26 & 42 & Clay & 1.43 \\
\hline B2 & $71-112$ & 36 & 30 & 34 & Clay loam & 1.27 \\
\hline B3 & $112-133$ & 30 & 34 & 36 & Clay loam & 1.38 \\
\hline B4 & $133^{+}$ & 26 & 34 & 40 & Clay & 1.45 \\
\hline \multicolumn{7}{|c|}{ Middle slope West-facing (MWF) Pedon } \\
\hline$A p_{1}$ & $0-22$ & 20 & 28 & 52 & Clay & 1.37 \\
\hline $\mathrm{Ap}_{2}$ & $22-43$ & 20 & 24 & 56 & Clay & 1.44 \\
\hline A & $43-63$ & 20 & 24 & 56 & Clay & 1.41 \\
\hline$A B$ & $63-75$ & 22 & 22 & 56 & Clay & 1.41 \\
\hline Bt1 & $75-95$ & 20 & 14 & 66 & Clay & 1.44 \\
\hline Bt2 & $95-142$ & 14 & 10 & 76 & Clay & 1.41 \\
\hline $\mathrm{Bt} 3$ & $142^{+}$ & 14 & 8 & 78 & Clay & 1.38 \\
\hline \multicolumn{7}{|c|}{ Upper slope West-facing (UWF) Pedon } \\
\hline A1 & $0-38$ & 31 & 34 & 35 & Clay loam & 1.25 \\
\hline A2 & $38-78$ & 31 & 36 & 33 & Clay loam & 1.36 \\
\hline Bt1 & $78-102$ & 19 & 22 & 59 & Clay & 1.37 \\
\hline Bt2 & $102-171$ & 19 & 22 & 59 & Clay & 1.26 \\
\hline $\mathrm{Bt} 3$ & $171^{+}$ & 15 & 20 & 65 & Clay & 1.43 \\
\hline \multicolumn{7}{|c|}{ Depression (DEP) Pedon } \\
\hline A1 & $0-20$ & 23 & 32 & 45 & Clay & 1.28 \\
\hline A2 & $20-50$ & 17 & 40 & 43 & Clay & 1.28 \\
\hline A3 & $50-70$ & 31 & 28 & 41 & Clay & 1.37 \\
\hline AC1 & $70-95$ & 27 & 30 & 43 & Clay & 1.33 \\
\hline AC2 & $95-120$ & 31 & 34 & 35 & Clay loam & 1.32 \\
\hline $\mathrm{C} 1$ & $120-150$ & 51 & 20 & 29 & Sandy clay loam & 1.45 \\
\hline $\mathrm{C} 2$ & $150-170$ & 47 & 22 & 31 & Sandy clay loam & 1.59 \\
\hline C3 & $170-200$ & 45 & 26 & 29 & Sandy clay loam & 1.20 \\
\hline C4 & 200-209 & 59 & 16 & 25 & Sandy clay loam & 1.34 \\
\hline C5 & $209-230$ & 27 & 36 & 37 & Clay loam & 1.20 \\
\hline C6 & $230-255$ & 36 & 26 & 38 & Clay loam & 1.30 \\
\hline C7 & $255^{+}$ & 20 & 36 & 44 & Clay & 1.43 \\
\hline
\end{tabular}




\subsubsection{Bulk Density}

Bulk density was highest in the surface horizon of the Pedon in the MEF followed by that in the MEF while the lowest in the UWF followed by the Depression area. The subsoil bulk density was highest $\left(1.66 \mathrm{~g} \mathrm{~cm}^{-3}\right)$ in the MEF and second $\left(1.59 \mathrm{~g} \mathrm{~cm}^{-3}\right)$ as well as lowest $\left(1.20 \mathrm{~g} \mathrm{~cm}^{-3}\right)$ were observed in the Depression area (Table 3). Generally, bulk density increased with depth primarily because of decrease in soil OM content and soil aggregation, as was indicated by the significant negative correlation between the two properties (Table 6). Soils that are loose, porous, or wellaggregated will have lower bulk densities than soils that are compacted or non-aggregated, as pore space (or air) weighs less than the solid space (soil particles) (weather.nmsu.edu/teaching material/soil252/Chapt5.htm 05/12/2007) .

The values of bulk density in the middle slope positions were relatively high, which might be attributed to cultivation. Secondary tillage (cultivation) generally decrease pore space and thus increases bulk density which stands as a reason for the higher bulk densities of the cropped soils than the uncropped soils. The movement of machinery over the field forces solid particles into spaces once occupied by water or air, resulting in less pore space and increased bulk density (weather.nmsu.edu/ teaching material/soil252/ Chapt5.htm 05/12/2007). Bulk density is an indirect measure of pore space and is affected primarily by texture and structure showing that as solid space and clay content increase, bulk density decreases.

\subsection{Chemical Properties}

\subsubsection{Soil pH}

The $\mathrm{pH}\left(\mathrm{H}_{2} \mathrm{O}\right)$ of the soil in the surface layers of the pedons was found to be slightly to moderately acidic, as per the rating of Jones (2003), with values ranging from 5.6 to 6.2 (Table 4). In all the soil profiles of the different landscape positions, soil $\mathrm{pH}$ measured in water was higher by about 1 2 units than the respective $\mathrm{pH}$ values measured in $\mathrm{KCl}$ solution. The low soil $\mathrm{pH}$ values with $\mathrm{KCl}$ determination indicate the presence of substantial quantity of exchangeable hydrogen ion. According to Mekaru and Uehara (1972) and Anon (1993), high soil acidity with $\mathrm{KCl}$ solution determination showed the presence of high potential acidity and relatively readily weatherable minerals.

\subsubsection{Cation Exchange Capacity and Exchangeable Bases}

The cation exchange capacity (CEC) of the soils across the surface and subsurface horizons ranged from 15.4 to 28.8 $\mathrm{cmol}(+) \mathrm{kg}^{-1}$. The surface soil CEC was the highest in the UEF pedon followed by the Depression while the lowest was observed in the MEF pedon (Table 4). The CEC values of the five pedons (UWF, MWF, FWF, MEF and FEF) could be considered as medium and that of the remaining two pedons (UEF and DEP) as high in accordance with the rating of Landon (1991). The CEC values of the pedons showed inconsistent relationship with depth (Table 4).

The concentrations of the basic exchangeable cations in the upper slopes were in the order of $\mathrm{Ca}>\mathrm{Mg}>\mathrm{K}>\mathrm{Na}$ (Table 4). The exchangeable Ca contents of the upper slope positions were more than quadruple as compared to that of the foot slope positions of the toposequences. The higher Ca content of the soils at the upper slope positions might be due to its strong adsorption to the soil colloids as compared to other cations, particularly $\mathrm{Na}$, because of its higher charge and small hydrated radius (Foth, 1990). However, the order of abundance the basic cations varied markedly along the toposequences which may be due to differences in land use system on the landscape positions. Similar to $\mathrm{Ca}$, the highest $\mathrm{Mg}$ contents were obtained in the upper slope positions, although the sub-soil layers of the MWF were rich in $\mathrm{Mg}$. Highest exchangeable $\mathrm{K}$ was recorded in the surface horizon of the MWF, and generally the middle and foot slope positions had more $\mathrm{K}$ content in surface horizons as compared to the upper slope positions in both east and west-facing sides (Table 4).

Exchangeable $\mathrm{Ca}$ and $\mathrm{Mg}$ were positively correlated with CEC, whereas the correlations of $\mathrm{Na}$ and $\mathrm{K}$ with $\mathrm{CEC}$ were negative (Table 6). The percent base saturation (52) was found to be highest in the surface horizon of the UEF pedon, whilst the lowest (26) was recorded in the surface horizon of FEF pedon. 
Table 4. Cation exchange capacity (CEC), exchangeable bases, ESP, and pH of the soils at the Kindo Koye Watershed.

\begin{tabular}{|c|c|c|c|c|c|c|c|c|c|c|}
\hline \multirow{2}{*}{$\begin{array}{l}\text { Depth } \\
(\mathrm{cm})\end{array}$} & \multirow{2}{*}{$\begin{array}{c}\mathrm{pH} \\
\left(\mathrm{H}_{2} \mathrm{O}\right)\end{array}$} & \multirow{2}{*}{$\underset{(\mathrm{KCl})}{\mathrm{pH}}$} & $\mathrm{Na}$ & $\mathrm{K}$ & $\mathrm{Ca}$ & $\mathrm{Mg}$ & \multirow{2}{*}{$\begin{array}{c}\text { *TEB } \\
\left(\mathrm{cmol}(+) \mathrm{kg}^{-1}\right)\end{array}$} & \multirow{2}{*}{$\begin{array}{c}\mathrm{CEC}(\mathrm{cmol}(+) \\
\left.\mathrm{kg}^{-1}\right)\end{array}$} & \multirow[b]{2}{*}{ PBS } & \multirow[b]{2}{*}{ ESP } \\
\hline & & & \multicolumn{4}{|c|}{$\left(\mathrm{cmol}(+) \mathrm{kg}^{-1}\right)$} & & & & \\
\hline \multicolumn{11}{|c|}{ Upper slope East-facing (UEF) Pedon } \\
\hline $0-40$ & 6.1 & 5.2 & 0.17 & 0.50 & 10.98 & 2.55 & 14.20 & 27.40 & 52 & 0.62 \\
\hline $40-64$ & 5.8 & 5.3 & 0.21 & 0.50 & 9.18 & 1.91 & 12.40 & 27.60 & 45 & 0.76 \\
\hline $64-90$ & 6.3 & 5.2 & 0.29 & 0.38 & 6.99 & 2.55 & 10.21 & 26.60 & 38 & 1.09 \\
\hline $90-136$ & 6.0 & 4.8 & 0.33 & 0.41 & 5.49 & 3.54 & 9.77 & 27.60 & 35 & 1.19 \\
\hline $136^{+}$ & 6.1 & 4.8 & 0.37 & 0.41 & 5.84 & 4.03 & 10.65 & 28.80 & 37 & 1.28 \\
\hline \multicolumn{11}{|c|}{ Middle slope East-facing (MEF) Pedon } \\
\hline $0-14$ & 6.2 & 4.5 & 0.62 & 2.03 & 1.77 & 0.28 & 4.70 & 17.20 & 27 & 3.60 \\
\hline $14-40$ & 6.1 & 4.7 & 0.87 & 1.55 & 1.98 & 0.25 & 4.65 & 16.60 & 28 & 5.24 \\
\hline $40-53$ & 6.1 & 4.8 & 0.96 & 1.97 & 1.61 & 0.64 & 5.18 & 16.90 & 31 & 5.68 \\
\hline $53-117$ & 6.6 & 4.8 & 0.84 & 3.69 & 1.15 & 0.45 & 6.13 & 16.70 & 37 & 5.03 \\
\hline $117-165$ & 6.7 & 5.1 & 0.84 & 5.11 & 1.12 & 0.43 & 7.50 & 18.00 & 42 & 4.67 \\
\hline $165^{+}$ & 6.7 & 5.1 & 0.90 & 5.43 & 1.18 & 0.51 & 8.02 & 17.20 & 47 & 5.23 \\
\hline \multicolumn{11}{|c|}{ Foot slope East-facing (FEF) Pedon } \\
\hline $0-18$ & 5.8 & 4.2 & 0.73 & 2.33 & 1.36 & 0.69 & 5.11 & 19.50 & 26 & 3.74 \\
\hline $18-53$ & 5.8 & 4.2 & 0.96 & 1.57 & 1.52 & 0.38 & 4.43 & 16.10 & 28 & 5.96 \\
\hline $53-100$ & 5.8 & 4.3 & 0.97 & 2.75 & 1.01 & 0.41 & 5.14 & 18.00 & 29 & 5.39 \\
\hline $100-160$ & 5.1 & 4.0 & 1.75 & 2.19 & 0.96 & 0.43 & 5.33 & 17.80 & 30 & 9.83 \\
\hline $160^{+}$ & 5.5 & 4.0 & 1.08 & 2.68 & 0.96 & 0.42 & 5.14 & 18.20 & 28 & 5.93 \\
\hline \multicolumn{11}{|c|}{ Foot slope West-facing (FWF) Pedon } \\
\hline $0-17$ & 5.8 & 4.4 & 0.77 & 3.50 & 1.04 & 0.25 & 5.56 & 20.60 & 27 & 3.74 \\
\hline $17-37$ & 5.7 & 4.3 & 0.69 & 2.95 & 0.81 & 0.32 & 4.77 & 20.20 & 24 & 3.41 \\
\hline $37-54$ & 5.8 & 4.3 & 0.85 & 2.16 & 1.01 & 0.21 & 4.23 & 17.60 & 24 & 4.83 \\
\hline $54-71$ & 5.6 & 4.2 & 0.99 & 1.65 & 1.19 & 0.34 & 4.17 & 19.50 & 21 & 5.08 \\
\hline $71-112$ & 5.8 & 4.3 & 0.76 & 1.46 & 1.17 & 0.22 & 3.61 & 21.00 & 17 & 3.62 \\
\hline $112-133$ & 5.7 & 4.3 & 0.79 & 1.16 & 1.28 & 0.21 & 3.44 & 19.50 & 18 & 4.05 \\
\hline $133^{+}$ & 5.2 & 4.0 & 0.87 & 1.04 & 1.03 & 0.30 & 3.24 & 19.10 & 17 & 4.55 \\
\hline \multicolumn{11}{|c|}{ Middle slope West-facing (MWF) Pedon } \\
\hline $0-22$ & 6.1 & 4.6 & 0.92 & 5.93 & 1.40 & 0.75 & 9.00 & 23.79 & 38 & 3.87 \\
\hline $22-43$ & 5.8 & 4.5 & 0.29 & 0.26 & 6.04 & 2.30 & 8.89 & 23.40 & 38 & 4.40 \\
\hline $43-63$ & 5.7 & 4.1 & 0.27 & 0.21 & 5.34 & 3.13 & 8.94 & 25.20 & 35 & 4.54 \\
\hline $63-75$ & 5.7 & 4.0 & 0.23 & 0.16 & 4.84 & 2.63 & 7.87 & 23.40 & 34 & 4.71 \\
\hline $75-95$ & 5.8 & 4.0 & 0.27 & 0.17 & 3.79 & 3.21 & 7.45 & 23.60 & 32 & 4.45 \\
\hline $95-142$ & 5.9 & 4.0 & 0.21 & 0.16 & 5.84 & 3.79 & 9.99 & 25.60 & 39 & 4.26 \\
\hline $142^{+}$ & 6.5 & 4.1 & 0.89 & 3.59 & 1.16 & 0.68 & 6.32 & 19.50 & 32 & 4.56 \\
\hline \multicolumn{11}{|c|}{ Upper slope West-facing (UWF) Pedon } \\
\hline $0-38$ & 5.6 & 4.4 & 0.15 & 0.14 & 6.94 & 2.47 & 9.70 & 23.20 & 42 & 0.65 \\
\hline $38-78$ & 5.9 & 4.4 & 0.20 & 0.21 & 7.24 & 1.88 & 9.13 & 24.40 & 37 & 0.82 \\
\hline $78-102$ & 5.3 & 4.4 & 0.44 & 0.18 & 6.34 & 2.88 & 9.85 & 26.20 & 38 & 1.68 \\
\hline $102-171$ & 5.2 & 4.1 & 0.52 & 0.17 & 3.64 & 1.23 & 5.56 & 25.00 & 22 & 2.08 \\
\hline $171^{+}$ & 5.6 & 3.8 & 0.40 & 0.17 & 6.29 & 1.56 & 8.42 & 24.40 & 35 & 1.64 \\
\hline \multicolumn{11}{|c|}{ Depression (DEP) Pedon } \\
\hline $0-20$ & 6.2 & 4.4 & 0.24 & 0.09 & 6.64 & 2.39 & 9.35 & 26.60 & 35 & 0.90 \\
\hline $20-50$ & 5.6 & 4.3 & 0.20 & 0.05 & 4.14 & 1.07 & 5.46 & 26.00 & 21 & 0.77 \\
\hline $50-70$ & 6.2 & 4.2 & 0.27 & 0.05 & 6.89 & 1.73 & 8.93 & 22.00 & 41 & 1.23 \\
\hline 70-95 & 6.0 & 4.3 & 0.98 & 1.02 & 1.51 & 0.32 & 3.83 & 16.40 & 23 & 5.98 \\
\hline $95-120$ & 5.9 & 4.4 & 0.98 & 1.37 & 1.60 & 0.34 & 4.29 & 15.40 & 28 & 6.36 \\
\hline $120-150$ & 6.3 & 4.4 & 0.96 & 1.86 & 1.22 & 0.23 & 4.27 & 19.50 & 22 & 4.92 \\
\hline $150-170$ & 6.1 & 4.4 & 0.38 & 0.11 & 7.49 & 3.70 & 11.68 & 24.60 & 47 & 1.54 \\
\hline $170-200$ & 6.5 & 4.4 & 0.29 & 0.07 & 6.09 & 2.55 & 9.00 & 21.20 & 42 & 1.37 \\
\hline $200-209$ & 6.6 & 4.5 & 0.27 & 0.07 & 4.69 & 1.32 & 6.35 & 15.60 & 41 & 1.73 \\
\hline $209-230$ & 6.1 & 4.4 & 0.40 & 0.11 & 7.98 & 3.37 & 11.86 & 25.40 & 47 & 1.57 \\
\hline $230-255$ & 6.5 & 4.6 & 0.42 & 0.11 & 5.49 & 2.47 & 8.48 & 24.40 & 35 & 1.72 \\
\hline $255^{+}$ & 5.8 & 4.4 & 0.38 & 0.48 & 8.23 & 3.70 & 12.80 & 28.20 & 45 & 1.34 \\
\hline
\end{tabular}




\subsubsection{Organic Carbon and Total Nitrogen}

The organic carbon $(\mathrm{OC})$ and total nitrogen $(\mathrm{N})$ contents of the soils decreased with depth in most pedons, and the surface horizons in the pits on the east-facing slope positions (UEF, MEF and FEF) contained relatively higher $\mathrm{OC}$ and total $\mathrm{N}$ than their respective west-facing pedons (Table 5). Generally, the pedon at the Depression area has relatively higher $\mathrm{OC}$ and total $\mathrm{N}$ than the other pedons except for OC in the UEF and MEF and for total $\mathrm{N}$ in the FEF. The range of soil OC contents in the surface horizons are considered as very low according to the ratings of Metson (1961), whereas the total $\mathrm{N}$ content of the surface horizons ranged from 0.115 (MEF) to $0.217 \%$ (FEF) (Table 5 ) and are considered as low to medium according to Havlin et al. (1999).

Organic carbon in the surface layer decreased down slope on east-facing toposequence. The highest organic carbon value of $2.16 \%$ was recorded in UEF, the front yard area used for cattle tethering, indicating higher content of organic carbon in uncultivated land as compared to its cultivated counterparts. Wakene and Heluf (2004) have also indicated that intensive cultivation aggravates OM oxidation and hence reduces OC content. Similarly, the organic carbon in surface layer decreased from UWF to MWF. However the FWF had higher organic carbon than MWF, which might be attributed to partial accumulation of the material from the upper and middle slopes. The total nitrogen content of the surface layers along toposequences followed similar trend with that of organic matter, except for the FEF pedon. The difference in OC and total $\mathrm{N}$ content among the pedons could be attributed to the effect of variation in the land use systems along the toposequences. In addition, higher $\mathrm{OC}$ and total $\mathrm{N}$ contents were recorded in the surface as compared to subsurface layers indicating strong correlation between them. However, their contents in the Depression pedon did not follow similar trend due to accumulation of contrasting material that add different materials from top parts through erosion in different years and water-logging, which might have affected decomposition and mineralization (Wang et al., 2000). Organic carbon and total nitrogen contents were positively correlated with available $\mathrm{P}$ and micronutrients, but negatively with clay (Table 6).

\subsubsection{Available Phosphorous}

Available phosphorus (P) contents of the soils in the surface horizons was highest in the UEF $\left(7.3 \mathrm{mg} \mathrm{kg}^{-1}\right)$ followed by FWF (4.54 $\left.\mathrm{mg} \mathrm{kg}^{-1}\right)$ and MEF $\left(4.2 \mathrm{mg} \mathrm{kg}^{-1}\right)$ while the lowest was recorded in the MWF $\left(0.64 \mathrm{mg} \mathrm{kg}^{-1}\right)$ pedon. Available $\mathrm{P}$ generally has inconstant relationship with depth in all pedons and irregularities were observed due to contrasting materials (Table 5). There is a general increase in the distribution of available $\mathrm{P}$ from top to bottom along the slope both on the east and west-facing toposequences. This is due to the fact that the relationship of slope position to soil properties is, to a great degree, controlled by erosion processes in that it alters the distribution of soil particles and water redistribution over the field. Kravchenko and Bullock (2000) found that in more than half of their study sites, slope was negatively correlated to CEC, organic matter, available $\mathrm{P}$, and exchangeable $\mathrm{K}$.

According to Havlin et al. (1999), the available P contents of the soils in the surface horizons are considered to be very low to low. The relatively higher available $\mathrm{P}$ in the surface horizons of most soil profiles as compared to that of subsurface layers could be attributed to the difference in organic matter contents of the layers. Available P content was positively correlated $(\mathrm{r}=0.41)$ with organic carbon (Table 6). High OM content and a good rate of its mineralization could ensure release of phosphate ions adequate for crop production, though most of the phosphate released in this way will be in the topsoil. If not immediately taken up by the plant or by soil organisms, however, it will be converted to non-labile form. Besides, the phosphate ions are most likely to combine with free iron or aluminum ions in acid soils to form iron III phosphates and aluminum phosphates, which are relatively insoluble (Ahn, 1993).

The decrease in available $\mathrm{P}$ content with depth in the pedons, except for the Depression pedon, is attributed to the increment of clay, as available $\mathrm{P}$ correlates negatively $(\mathrm{r}$ $=-0.56$ ) with clay content (Table 6). Iron and aluminum oxides are intimately associated with the kaolinitic clay fraction of the soil or as coatings on the clay, and thereby increase $\mathrm{P}$ fixation. Fixation is thus related to soil texture and would be expected to be greater in clayey soils than in light textured ones. This applies particularly when the clay is kaolinitic (Ahn, 1993). Available P had also a very highly significant correlation with $\mathrm{Fe}, \mathrm{Zn}$ and $\mathrm{Cu}$, and high correlation with Mn (Table 6).

\subsubsection{Available Micronutrients ( $\mathrm{Fe}, \mathrm{Mn}, \mathrm{Zn}$ and $\mathrm{Cu}$ )}

The micronutrients contents in all pedons decreased with increasing soil depth (Table 5). The order of micronutrients concentration in the pedons was $\mathrm{Mn}>\mathrm{Zn}>\mathrm{Fe}>\mathrm{Cu}$, except for east-facing foot slope where $\mathrm{Zn}>\mathrm{Mn}>\mathrm{Fe}>$ $\mathrm{Cu}$ was recorded.

The concentrations of $\mathrm{Cu}$ and $\mathrm{Fe}$ are very low and that of $\mathrm{Mn}$ and $\mathrm{Zn}$ fall in low to high ranges as compared with the normal ranges of these nutrients in soil (Havlin et al., 1999). The trend of $\mathrm{Mn}$ concentration under different slope positions was similar to that of $\mathrm{Fe}$ distribution (Table 5) indicating that these two elements have similar chemical behavior in tropical soils (Kravskoof, 1972).

The distribution of CU was consistently decreased from the surface to the subsurface horizons, which might be attributed to the strong association of $\mathrm{Cu}$ with soil organic matter. There was also a positive correlation between copper and organic matter showing that copper is strongly complexed with organic matter as was also described earlier by Wakene and Heluf (2004). Moreover, the Fe and Mn contents were also decreased consistently with depth in the profiles of every landscape positions. 
Table 5. Total nitrogen, organic carbon (OC) and available phosphorus and micronutrients contents of the soils at the Kindo Koye Watershed.

\begin{tabular}{|c|c|c|c|c|c|c|c|c|}
\hline $\begin{array}{l}\text { Depth } \\
(\mathrm{cm})\end{array}$ & $\begin{array}{c}\text { Total } \mathrm{N} \\
(\%)\end{array}$ & $\begin{array}{l}\mathrm{OC} \\
(\%)\end{array}$ & $\begin{array}{l}\mathrm{C} / \mathrm{N} \\
\text { ratio }\end{array}$ & $\begin{array}{c}\text { Available P } \\
\left(\mathrm{mg} \mathrm{kg}^{-1}\right)\end{array}$ & $\begin{array}{c}\mathrm{Fe} \\
\left(\mathrm{mg} \mathrm{kg}^{-1}\right)\end{array}$ & $\begin{array}{c}\mathrm{Mn} \\
\left(\mathrm{mg} \mathrm{kg}^{-1}\right)\end{array}$ & $\begin{array}{c}\mathrm{Zn} \\
\left(\mathrm{mg} \mathrm{kg}^{-1}\right)\end{array}$ & $\begin{array}{c}\mathrm{Cu} \\
\left(\mathrm{mg} \mathrm{kg}^{-1}\right)\end{array}$ \\
\hline \multicolumn{9}{|c|}{ Upper slope East-facing (UEF) Pedon } \\
\hline $0-40$ & 0.178 & 2.163 & 12 & 7.30 & 1.39 & 4.51 & 10.23 & 0.18 \\
\hline $40-64$ & 0.140 & 1.344 & 10 & 1.40 & 0.59 & 0.53 & 3.94 & 0.11 \\
\hline $64-90$ & 0.113 & 0.789 & 7 & 0.92 & 1.06 & 0.40 & 3.41 & 0.31 \\
\hline $90-136$ & 0.070 & 0.481 & 7 & 0.92 & 0.59 & 0.95 & 0.79 & 0.18 \\
\hline $136^{+}$ & 0.090 & 0.585 & 7 & 1.66 & 0.37 & 0.44 & 0.48 & 0.15 \\
\hline \multicolumn{9}{|c|}{ Middle slope East-facing (MEF) Pedon } \\
\hline $0-14$ & 0.115 & 1.948 & 17 & 4.20 & 1.19 & 3.83 & 6.09 & 0.18 \\
\hline $14-40$ & 0.185 & 1.318 & 7 & 1.34 & 0.79 & 4.80 & 2.49 & 0.24 \\
\hline $40-53$ & 0.132 & 1.127 & 9 & 1.34 & 0.37 & 0.88 & 1.91 & 0.18 \\
\hline $53-117$ & 0.110 & 0.879 & 8 & 1.34 & 0.66 & 0.84 & 1.17 & 0.07 \\
\hline $117-165$ & 0.123 & 0.813 & 7 & 2.34 & 0.37 & 0.29 & 0.40 & 0.13 \\
\hline $165^{+}$ & 0.070 & 0.530 & 8 & 2.20 & 0.55 & 0.20 & 0.66 & 0.13 \\
\hline \multicolumn{9}{|c|}{ Foot slope East-facing (FEF Pedon } \\
\hline $0-18$ & 0.217 & 1.743 & 8 & 2.30 & 1.03 & 8.78 & 7.96 & 0.20 \\
\hline $18-53$ & 0.153 & 1.743 & 11 & 1.30 & 2.57 & 7.55 & 7.52 & 0.24 \\
\hline $53-100$ & 0.137 & 0.905 & 7 & 0.34 & 0.66 & 0.81 & 1.76 & 0.15 \\
\hline $100-160$ & 0.112 & 0.813 & 7 & 0.30 & 0.51 & 0.33 & 0.62 & 0.18 \\
\hline $160^{+}$ & 0.098 & 0.720 & 7 & 0.30 & 0.18 & 0.15 & 0.70 & 0.07 \\
\hline \multicolumn{9}{|c|}{ Foot slope West-facing (FWF) Pedon } \\
\hline $0-17$ & 0.127 & 1.555 & 12 & 4.54 & 2.20 & 7.22 & 6.40 & 0.20 \\
\hline $17-37$ & 0.108 & 1.113 & 10 & 2.48 & 1.36 & 7.11 & 5.30 & 0.15 \\
\hline $37-54$ & 0.148 & 0.966 & 7 & 1.98 & 1.30 & 5.30 & 4.36 & 0.13 \\
\hline $54-71$ & 0.141 & 1.325 & 9 & 1.98 & 1.72 & 4.60 & 4.29 & 0.15 \\
\hline $71-112$ & 0.160 & 1.452 & 9 & 1.90 & 1.85 & 11.97 & 7.15 & 0.29 \\
\hline $112-133$ & 0.140 & 1.662 & 12 & 2.56 & ND & 6.27 & 8.07 & 0.24 \\
\hline $133^{+}$ & 0.143 & 1.489 & 10 & 2.56 & 3.48 & 9.77 & 8.36 & 0.22 \\
\hline \multicolumn{9}{|c|}{ Middle slope West-facing (MWF) Pedon } \\
\hline $0-22$ & 0.116 & 1.069 & 9 & 0.64 & 0.70 & 0.59 & 3.85 & 0.07 \\
\hline $22-43$ & 0.109 & 1.051 & 10 & 0.46 & 0.73 & 0.20 & 3.15 & 0.13 \\
\hline $43-63$ & 0.092 & 0.879 & 10 & 1.18 & 0.66 & 0.33 & 2.64 & 0.13 \\
\hline $63-75$ & 0.095 & 0.668 & 7 & 1.12 & 0.66 & 0.81 & 2.53 & 0.11 \\
\hline $75-95$ & 0.070 & 0.554 & 8 & 1.00 & 0.37 & 0.62 & 2.02 & 0.07 \\
\hline $95-142$ & 0.049 & 0.513 & 10 & 1.00 & 0.29 & 0.24 & 1.14 & 0.13 \\
\hline $142^{+}$ & 0.028 & 0.358 & 13 & 1.00 & 0.31 & 0.24 & 0.51 & 0.04 \\
\hline \multicolumn{9}{|c|}{ Upper slope West-facing (UWF) Pedon } \\
\hline $0-38$ & 0.146 & 1.572 & 11 & 1.38 & 2.22 & 8.16 & 8.58 & 0.22 \\
\hline $38-78$ & 0.115 & 1.407 & 12 & 1.20 & 2.09 & 3.21 & 8.07 & 0.24 \\
\hline $78-102$ & 0.085 & 0.880 & 10 & 0.56 & 0.57 & 0.92 & 2.73 & 0.13 \\
\hline $102-171$ & 0.092 & 0.657 & 7 & 0.56 & 0.44 & 0.37 & 2.24 & 0.13 \\
\hline $171^{+}$ & 0.070 & 0.491 & 7 & 0.28 & 0.33 & 0.68 & 1.23 & 0.18 \\
\hline \multicolumn{9}{|c|}{ Depression (DEP) Pedon } \\
\hline $0-20$ & 0.189 & 1.890 & 10 & 1.50 & 1.43 & 9.79 & 6.62 & 0.31 \\
\hline $20-50$ & 0.185 & 1.638 & 9 & 1.50 & 1.45 & 6.89 & 6.25 & 0.22 \\
\hline $50-70$ & 0.168 & 1.134 & 7 & 1.24 & 1.63 & 6.93 & 7.04 & 0.11 \\
\hline $70-95$ & 0.143 & 1.239 & 9 & 1.80 & 1.19 & 5.43 & 5.48 & 0.31 \\
\hline $95-120$ & 0.169 & 1.155 & 7 & 2.42 & 1.52 & 4.93 & 4.84 & 0.31 \\
\hline $120-150$ & 0.112 & 0.819 & 7 & 3.60 & 1.87 & 7.85 & 5.90 & 0.29 \\
\hline $150-170$ & 0.126 & 0.945 & 8 & 4.30 & 1.32 & 6.23 & 5.52 & 0.29 \\
\hline $170-200$ & 0.115 & 1.176 & 10 & 4.18 & 1.83 & 6.18 & 6.09 & 0.24 \\
\hline 200-209 & 0.147 & 0.990 & 7 & 3.70 & 2.42 & 12.56 & 5.52 & 0.33 \\
\hline $209-230$ & 0.112 & 1.197 & 11 & 5.20 & 1.01 & 2.79 & 4.51 & 0.24 \\
\hline $230-255$ & 0.113 & 0.882 & 8 & 4.60 & 1.08 & 1.36 & 3.98 & 0.22 \\
\hline $255^{+}$ & 0.147 & 1.113 & 8 & 6.36 & 4.93 & 2.95 & 5.30 & 0.40 \\
\hline
\end{tabular}




\subsection{Classification of the Soils}

The dominant soils of the area were previously mapped as Eutric Nitosols (EMA, 1988). The soil profiles, except that of the depression, had thick (37 to 78) surface horizons, having moist color of $7.5 \mathrm{YR} 5 / 2$ and dark and very weak to weak structure. The organic carbon content of the surface horizons of the pedons ranged from 1.05 to $1.95 \%$ with percent base saturation values of less than 50 using $1 \mathrm{M}$ $\mathrm{NH}_{4} \mathrm{OAc}$ at $\mathrm{pH}$ 7. Thus, the six pedons possessed umbric epipedons, whereas the pedon on the depression failed to meet criteria for any other epipedons except Ochric.

In the subsurface horizons of all, but FWF pedon, thick horizons $(133$ to $171 \mathrm{~cm})$ with clay contents ranging from 51 to $81 \%$ were observed. The clay contents of the subsurface horizons were found to be more than 1.2 times greater than their respective surface layers, the subsurface horizons contained $8 \%$ more clay than the horizon above where the horizon above had more than $40 \%$ clay and these clay increments were found within distances less than $15 \mathrm{~cm}$ (Table 4). The apparent cation exchange capacities of the horizons ranged between 25 and $88 \mathrm{cmol}(+) \mathrm{kg}^{-1}$. Besides, faint and prominent pedfaces, argillians, were observed in the horizons. These properties would therefore qualify the horizons of the five pedons as argillic subsurface diagnostic horizons as described by Buol et al. (2003). Considering these features, the five pedons were grouped under Ultisols. The subsurface layers of the FWF pedon did not show clay increment, although there was evidence of color alteration indicating that it possesses cambic horizons. In addition, it has base saturation less than $50 \%$ using $1 \mathrm{M} \mathrm{NH}_{4} \mathrm{OAc}$ at $\mathrm{pH}$ 7 between the umbric epipedon and a depth of $180 \mathrm{~cm}$. Thus, it was classified as Inceptisols, whereas the pedon at the Depression without any diagnostic horizon was classified as Entisols.

The region is characterized by isothermic temperature and ustic moisture regimes based on the estimates made using the mean annual and monthly temperature and moisture distributions of the region, respectively (Van Wambeke, 2003). Thus, the five pedons were classified as Ustults on the bases of soil moisture regime at the suborder level. Further, the pedons did not have a densic, lithic, paralithic or petroferric contact within $150 \mathrm{~cm}$; and did not have a clay decrease of $20 \%$ or more from the maximum clay content. Hence, they were classified as Paleustults and Typic Paleustults at great groups and subgroups, respectively (Table 7).

Considering the ustic soil moisture regime, absence of free carbonates within $200 \mathrm{~cm}$ of the mineral soil surface and base saturation (1M NH $4 \mathrm{OAc}$ ) of less than $60 \%$ in all horizons at a depth between 25 and $75 \mathrm{~cm}$ from the mineral soil surface and the presence of umbric epipedon, the the FWF pedon was further classified as Ustepts, Dystrustepts and Humic Dystrustepts at suborder, great groups and subgroup levels, respectively (Table 7).

The pedon at the Depression was classified as Fluvents based on the features such as $<25 \%$ slope, $0.2 \%$ or more
OC and irregular decrease in OC content from a depth of $25 \mathrm{~cm}$ to $125 \mathrm{~cm}$. This Depression area pedon was further classified as Aquic Usticfluvents due to ustic soil moisture regime with seasonal aquic conditions.

The classification of the soils of the five pedons as Ultisols, and that of FWF and DEP as Inceptisols and Entisols, respectively, was a major deviation from the previous soil map (EMA, 1988). The position of the FWF and DEP pedons on the catena makes these orders different from the rest of the pedons in the area and showing the influence of topography on soil development.

The five pedons, which were grouped under Ultisols following Soil Taxonomy, were classified as Acrisols due to the presence of an argillic B horizon; having a base saturation which is less than $50 \%$ in, at least, some part of the $\mathrm{B}$ horizon within $125 \mathrm{~cm}$ of the surface. They were further grouped under Ferric Acrisols at the unit level because of their ferric properties (Table 7)

The FWF pedon was categorized as Dystric Cambisols due to the presence of an umbric A horizon, which is more than $25 \mathrm{~cm}$ thick a base saturation of less than $50 \%$ in at least some part of the $\mathrm{B}$ horizon. The pedon at the depression was categorized under Dystric Fluvisols as it developed from recent alluvial deposits, and had no diagnostic horizons other than an ochric $A$ and base saturation of less than $50 \%$, at least in some part of the soil between 20 and $50 \mathrm{~cm}$ from the surface (Table 7).

Contrary to the report of the EMA (1988), the present study revealed the existence of three soil orders or mapping units within the catena. This is a result of detail survey and classification of soils and shows that topography has a great influence on soil development.

\section{Conclusions}

The soils of a catena could differ as a result of erosion, transport and deposition of surface materials as well as leaching, translocation and deposition of chemicals and particulate constituents in the soil. Topography plays a major role in these processes and thereby influences the development and characteristics of the soils along the toposequences. Most of the important soil quality indicators such as bulk density, structure, OC, soil $\mathrm{pH}, \mathrm{CEC}$, total $\mathrm{N}$, available $\mathrm{P}$, exchangeable bases, and available micronutrients were influenced by the different landscape positions, particularly at the surface horizon. Continuous intensive cultivation without appropriate soil management practices has contributed to the degradation of the important soil quality indicators. Therefore, reducing intensive cultivation, and integrated use of inorganic and organic fertilizers could replenish the degraded soil quality parameters for sustainable productivity. However, further study of the areas is recommended especially with respect to soil landscape - land management relationships so as to give sound conclusion for the sustainable use of the land. 
Table 6. Correlation between properties of the soils in Kindo Koye watershed catena.

\begin{tabular}{|c|c|c|c|c|c|c|c|c|c|c|c|c|c|}
\hline & $\mathrm{BD}$ & $\mathrm{Na}$ & $\mathrm{K}$ & $\mathrm{Ca}$ & $\mathrm{Mg}$ & CEC & Total N & $\mathrm{OC}$ & Av. P & $\mathrm{Fe}$ & $\mathrm{Mn}$ & $\mathrm{Zn}$ & $\mathrm{Cu}$ \\
\hline Clay & 0.296 & 0.107 & 0.263 & -0.123 & 0.184 & 0.151 & $-0.660^{* *}$ & $-0.693^{* *}$ & $-0.564^{* *}$ & $-0.586^{* *}$ & $-0.753^{* *}$ & $-0.862^{* *}$ & $-0.618^{* *}$ \\
\hline $\mathrm{BD}$ & & 0.157 & 0.263 & -0.165 & 0.000 & -0.044 & -0.269 & -0.387 & -0.095 & -0.121 & -0.259 & -0.323 & -0.152 \\
\hline $\mathrm{Na}$ & & & $0.664^{* *}$ & $-0.826^{* *}$ & $-0.756^{* *}$ & $-0.731^{* *}$ & 0.049 & -0.062 & -0.182 & -0.093 & -0.028 & -0.228 & -0.092 \\
\hline K & & & & $-0.696^{* *}$ & $-0.633^{* *}$ & $-0.529^{*}$ & -0.097 & -0.102 & -0.097 & -0.176 & -0.165 & -0.277 & -0.377 \\
\hline $\mathrm{Ca}$ & & & & & $0.828^{* *}$ & $0.797^{* *}$ & -0.009 & 0.069 & 0.284 & 0.122 & -0.115 & 0.191 & 0.193 \\
\hline $\mathrm{Mg}$ & & & & & & $0.815^{* *}$ & -0.300 & -0.252 & 0.158 & 0.005 & -0.282 & -0.108 & 0.070 \\
\hline CEC & & & & & & & -0.188 & -0.083 & 0.088 & -0.004 & -0.260 & 0.015 & 0.004 \\
\hline TN & & & & & & & & $0.782^{* *}$ & 0.283 & $0.416^{*}$ & $0.662^{* *}$ & $0.673^{* *}$ & $0.497^{*}$ \\
\hline $\mathrm{OC}$ & & & & & & & & & $0.414^{*}$ & $0.428^{*}$ & $0.627^{* *}$ & $0.840^{* *}$ & 0.390 \\
\hline Av. P & & & & & & & & & & $0.526^{*}$ & 0.352 & $0.501^{* *}$ & $0.478^{*}$ \\
\hline $\mathrm{Fe}$ & & & & & & & & & & & $0.588^{* *}$ & $0.606^{* *}$ & $0.646^{*}$ \\
\hline $\mathrm{Mn}$ & & & & & & & & & & & & $0.782^{* *}$ & $0.585^{* *}$ \\
\hline $\mathrm{Zn}$ & & & & & & & & & & & & & $0.517^{*}$ \\
\hline
\end{tabular}

Table 7. Classification of the soils of Kindo Koye watershed catena following Soil Taxonomy and the WRB Systems.

\begin{tabular}{|c|c|c|c|c|c|c|}
\hline \multirow[b]{2}{*}{ Pedon* } & \multicolumn{4}{|c|}{ Soil Taxonomy } & \multicolumn{2}{|c|}{ The WRB legend } \\
\hline & Order & Suborder & Great group & Subgroup & Major Groups & Units \\
\hline UEF & Ultisols & Ustults & Paleustults & Typic Paleustults & Acrisols & Ferric Acrisols \\
\hline MEF & Ultisols & Ustults & Paleustults & Typic Paleustults & Acrisols & Ferric Acrisols \\
\hline $\mathrm{FEF}$ & Ultisols & Ustults & Paleustults & Typic Paleustults & Acrisols & Ferric Acrisols \\
\hline DEP & Entisols & Fluvents & Usticfluvents & Aquic Ustivfluvents & Fluvisols & Dystric Fluvisols \\
\hline FWF & Inceptisols & Ustepts & Dystrustepts & Humic Dystrustepts & Cambisols & Dystric Cambisols \\
\hline MWF & Ultisols & Ustults & Paleustults & Typic Paleustults & Acrisols & Ferric Acrisols \\
\hline UWF & Ultisols & Ustults & Paleustults & Typic Paleustults & Acrisols & Ferric Acrisols \\
\hline
\end{tabular}

Upper slope east-facing 


\section{Acknowledgments}

We would like to thank B.B. Mishra, Alemayehu Kiflu, Dereje Tsegaye, Fitsum Tekly, Gifole Gidago and Tigist Yimer for their kind assistance in fieldwork. We also extend our gratitude to the CIDA/UPCD Project for providing the financial support for the fieldwork and analytical service costs of the study.

\section{References}

Ahn, P.M. 1993. Tropical Soils and Fertilizer Use. Longman Group UK Limited, UK.

Anon. 1993. Soil Chemical Analysis. Part I, Vol. 1. Improvement of soil services for Agricultural development.

Brady, N.C. and Weil, R.R. 2002. The Nature and Properties of Soils.13 th edition. Saurabh Printers Pvt. Ltd., India.

Bremner, J.M. and Mulvaney, C.S. 1982. Nitrogen-total. In: Page, A.L. (ed.). Methods of Soil Analysis. Part 2. Chemical and microbiological properties. SSSA, Madison, Wisconsin. pp. 595-641.

BSI (British Standards Institution). 1975. Methods of testing soils for civil engineering purpose. British standards 1377. British standards institution, Landon.

Buol, S.W., Southard, R.J. Graham, R.C. and McDaniel, P.A. 2003. Soil Genesis and Classification, Fifth edition. Iowa state University Press. Ames, USA.

Chadwick, O.A. and Grahm, R.C. 2000. Pedogenic processes. In: Sumner, M.E. (ed.). Handbook of soil science. CRC Press, Boca Raton. pp. 41-75.

Chopra, S.H. and Kanwar, J.S. 1976. Analytical agricultural chemistry. Kalyani Publisher Ludhiana, New Delhi, Indian. p. 518. En. wikipedia.org/wiki/Soil_pH. (Accessed on 25/12/2007)

EMA (Ethiopian Mapping Authority). 1988. National Atlas of Ethiopia, Addis Ababa, Ethiopia.

FAO (Food and Agricultural Organization). 1984. Agro climatic data for Africa.V.1. Countries North of the equator. FAO Plant Production and Protection series No.22. Rome.

FAO (Food and Agricultural Organization). 1990. Guidelines for Soil Profile Description. $3^{\text {rd }}$ edition. Soil Resources, Management and Conservation Service, Land and water Development Division, FAO, Rome.

FAO/WRB (Food and Agricultural Organization/World Resource Bare for Soil Resources). 2006. World Resources Report No. 103. $2^{\text {nd }}$ Edition. FAO, Rome, Italy.

Fikre, M. 2003. Pedogenesis of major volcanic soils of the south central rift valley Region, Ethiopia. MSc Thesis. University of Saskatchewan. Saskatoon, Canada. pp. 128.

Foth, H.D. 1990. Fundamentals of Soil Science. 12 ${ }^{\text {th }}$ edition. John Willey and Sons .New York. Grunwald.ifas.ufl.edu/Nat_resources/organic_matter/ organic.htm (Accessed on 02/08/2009).

Havlin, J.L., Beaton, J.D. Tisdale, S.L. and Nilson, W.L. 1999. Soil Fertility and Fertilizers: An Introduction to Nutrient Management. $6^{\text {th }}$ edition. Prentice hall. Upper Saddle River, New Jersey.
Irvin, B.J. 1996. Spatial Information Tools for Delineating Landform Elements to Support Soil/Landscape Analysis. PhD Thesis, University of WisconsinMadison. grunwald.ifas.ufl.edu/Nat_resources/soil_for ming_factors/formation.htm (Accessed on 05/12/2007).

Jones, J.B. 2003. Agronomic Handbook: Managiment of Crops, Soils and Their Fertility. CRC Press LLC, Bxa Ratan, FL, USA.

Kravchenko, A.N. and Bullock, D.G. 2000. Correlation of corn and soybean grain yield with topography and soil properties. Argon. J. 92: 75-83.

Kravskoof, K.B. 1972. Geochemistry of micronutrients. In: Mortued, J.J. (ed.). Soil Sci. Soc. Am. Proc, Madison, Wisconsin, USA. pp. 7-40.

Landon, J.R. 1991. Booker tropical soil manual: a handbook for soil survey and agricultural land evaluation in the tropics and subtropics. Long man scientific and technical. Booker Tate Ltd. John Wiley and Sons, Inc., New York.

Lawrence, W. M.1992. The variation of soil erodibility with slope position in a cultivated Canadian prairie landscape. Earth Surface Processes and Landforms. Vol. 17, Issue 6, Wiley and Sons, Ltd. pp. 543-556.

Mekaru, T. and Uehara, G. 1972. Anion adsorption in ferruginous tropical soils. Soil Sci. Soc. Am. Proc. 36: 296300.

Mesfin, A. 1998. Nature and management of Ethiopian soils. Alemaya University of Agriculture. Alemaya, Ethiopia.

Metson, A.J. 1961. Methods of Chemical Analysis for Soil Survey Samples. New Zealand DSIR Soil Bur Bull 12. Govt Printer, Wellington, New Zealand.

Miller, P.M., Singer, M.J. and Nielsen, D.R. 1998. Spatial variability of wheat yields and soil properties on complex hills. Soil Sci. Soc. Am. J. 52: 1133-1141.

Moore, I.D., Gessler, P.E., Nielsen, G.A. and Peterson, G.A. 1993. Soil attributes prediction using terrain analysis. Soil Sci. Soc. Am. J. 57: 443-452.

Rust, R.H. 1983. Alfisols. In: Wilding, L.P., Smeck, N.E. and Hall, G.F. (eds.). Pedogenesis and Soil Taxonomy II. The soil orders. Elsevier Science Publishers, Amsterdam. pp. 253-281.

Sahlemedhin, S. and Taye, B. 2000. Procedure for soil and plant analysis. National Soil Research Centre, Ethiopian Agricultural Research Organization, Addis Ababa, Ethiopia. p. 110.

SAS .1997. SAS Institute Inc., Cary. NC. USA.

Soil Survey Staff. 1999. Soil Taxonomy: a basic system of classification for making and Interpreting soil surveys, USDA-NRCS. US Government printing office, Washington, DC.

Tan, K.N. 1996. Soil Sampling, Preparation and Analysis. Marcel Dekker, Inc, New York.

Van Ranst, E., Verloo, M., Demeyer, A. and Pauwels, J.M. 1999. Manual for the soil chemistry and fertility laboratory: analytical methods for soils and plants, equipment and management of consumables. University of Gent, Belgium. 
Van Reeuwijk. 1993. Procedures for Soil Analysis. $4^{\text {th }}$ Edition. International soil reference and Information center, Netherlands.Weather.nmsu.edu/teaching_Mater $\mathrm{ial} /$ soil252/Chapt5.htm (Accessed on 05/12/2007).

Van Wambeke, A. 2003. Properties and Management of Soils of the Tropics. Food and Agriculture Organization (FAO) of the United Nations.

Wakene, N. and Heluf, G. 2004. The impact of different land use systems on soil quality of western Ethiopia Alfisols. International Research on Food Security: Natural Resource Management and Rural Poverty
Reduction through Research for Development and Transformation. Deutcher Tropentage-Berlin 5-7 October 2004. pp. 1-7. http://www. Tropentage. de /2004/abstracts/full/265.pdf

Wang, J., Bojie, F., Yang, Q. and Liding, C. 2000. Soil nutrients in relation to land use and landscape position in the semi-arid small catchments on the loess plateau in China. Department of Systems Ecology, Research Center for Eco-Environmental Sciences, Chinese Academy of Sciences, China. J. Arid. Environ. Online at http://www.ideallibrary.com.,48:537-550. 